\title{
Homenagem à Professora Isabel Ribeiro do Valle Teixeira
}

Isabel Ribeiro do Valle Teixeira tem 11 anos de experiência na educação superior, durante os quais trabalhou paralelamente como professora e pesquisadora. Docente e coordenadora da licenciatura em ciências biológicas do campus Muzambinho do IFSULDEMINAS (Instituto Federal de Educação, Ciência e Tecnologia do Sul de Minas Gerais), Isabel lembra que não é recente sua ligação com a região. "Nasci em Guaranésia", diz. "Eu era criança e brincava nos arredores do câmpus. Mas naquela época era Escola Agrotécnica Federal de Muzambinho. Meu pai foi um dos professores".

O fascínio do pai pela natureza, que o levava a ser grande naturalista amador, influenciou as escolhas profissionais de Isabel, que se dedicou à entomologia durante o curso de ciências biológicas concluído em 1994 na USP de Ribeirão Preto. Logo vieram, pela mesma universidade, o mestrado em 1996 e o doutorado em 2002, ambos focados nesse ramo científico que investiga os insetos. Isabel estudou predadores de grãos, principalmente os devoradores de feijão armazenado, leguminosa que constitui uma das mais importantes fontes de proteínas da América Latina e da África.

Sua carreira como docente começou formando professores de biologia, em 2001, no Centro Universitário de Guaxupé, cidade do sul de Minas Gerais situada entre Guaranésia e Muzambinho. Sua colaboração com revistas científicas iniciou um ano depois, na Revista Expressão. Hoje, Isabel contribui como avaliadora também de revistas internacionais, como Journal of Plant Breeding and Crop Science e International Journal of Nutrition and Metabolism, e integra o conselho editorial da Revista Agrogeoambiental desde 2011. "Percebo algo especial nessa revista, um desejo de progredir", diz.

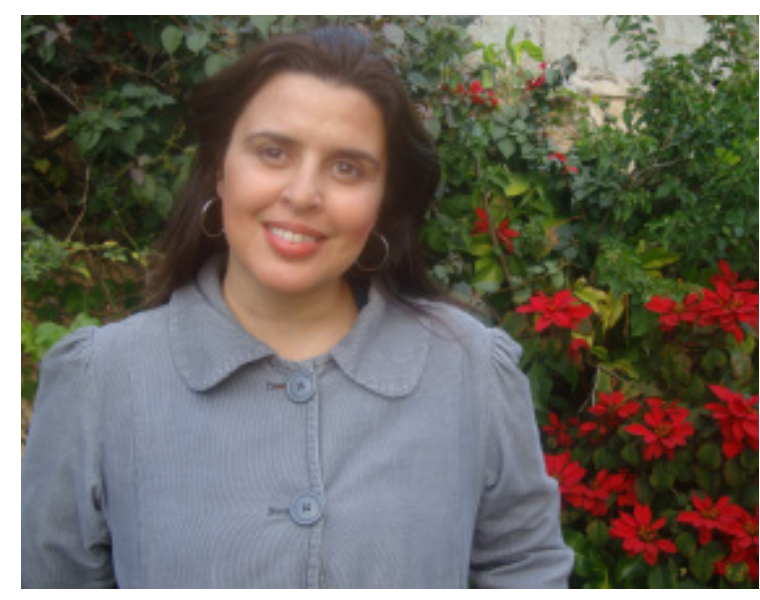

"É possível um mundo melhor? Trabalhar como educadora é minha forma de dizer que sim." 